\title{
MONITORING CIVIL ENGINEERING STUDENTS' METACOGNITIVE AWARENESS DURING INDEPENDENT ENGLISH SPEAKING CLUB ACTIVITIES
}

\author{
Tabita Hermayani ${ }^{1}$, Concilianus Laos Mbato ${ }^{2}$ \\ ${ }^{1}$ Sanata Dharma University Yogyakarta, Indonesia \\ ${ }^{2}$ Sanata Dharma University Yogyakarta, Indonesia \\ ${ }^{1}$ ataherma17@gmail.com, ${ }^{2}$ cons@usd.ac.id
}

\begin{abstract}
The global market's growth influences the increasing need of English speaking proficiency for many professions. Hence, non-English department students equip themselves with English speaking proficiency. Some take courses in some informal institutions; others make their own independent English club. A group of metacognitive Civil Engineering students in Indonesia formed a Speaking Club to facilitate their learning. The research aimed to measure the metacognitive awareness of some Civil Engineering students during their independent learning activities. The analysis was done by using the Metacognitive Awareness Inventory (MAI). To triangulate the data, interviews, observation and critical reflection were used. From the research it could be concluded that independent learning can be facilitated and born from cooperative learning. Cooperative learning builds up learners' motivation through peer feedbacks and monitoring done by a tutor. Metacognitive awareness was built upon the realization of clear learning objectives, followed by self-determination, and planning. Consistency is also required to sustain self-regulated learning.
\end{abstract}

Keywords: Metacognitive Awareness, Speaking, Learning Strategy

\section{INTRODUCTION}

The issue of speaking anxiety in learning English as a foreign language is a common occurrence in non-English speaking country around the world. As noticeable as the issue may be, little attention was given to further elaborate the solutions to which such speakers may overcome their difficulties (Tsiplakides and Keramida, 2009; Al Hosni, 2014). In developing countries such as Indonesia, where infrastructural project developments are currently being worked in an extensive growth, students of Civil Engineering are also expected to speak good English. Accompanied by the rapid growth of e-commerce and the greater effects of global market towards different aspects of Indonesians' life, the significance of speaking fluent English is even more urgent (Rahayu and Day, 2015). This issue was highlighted by Crystal (2012) by suggesting that English, as the Lingua Franca, is used in every sector of economy as the main bridge to build international communication grid (p. 3). Undergraduates of all subjects, including the Civil Engineering students, who would one day take over the economic wheel of this nation, must develop their English speaking skill effectively to meet the world's demand (Basturkmen, 2014).

Since the year 2014, Indonesia has been working on its infrastructure developments across different areas in its provinces. This has been the major project of the nation to boost the economic growth (Yamin and Windymadaksa, 2017; Nugraha, 2018). According to Fitriandi, Kakinaka and Kotani (2014), development in the infrastructure sector is vital to the nation's economic growth as it would also draw foreign investors. With this background comes the need 
of spoken English competency by the Indonesian Civil Engineering graduates as they would be the ones who are in charge of the infrastructure development sector and communicating with English speaking foreigners when it is needed. The need was realized by the Civil Engineering department of a renowned private university in Yogyakarta, Indonesia.

To accommodate the need of professional engineers who speak good English, the university included English as part of its obligatory courses. The courses are to be taken in the first two semesters in the whole credit programs. Unfortunately, the courses were too short and deemed insufficient for the undergraduate students. Some students who were interested in expanding their English competency decided to establish an independent English speaking club. By adopting Cooperative Language Learning (CLL) strategies, they gathered materials from various credible online sources and the designed informal meetings every week. In turn, these students were orderly assigned to design simple learning plans with its topics, games, or other activities agreed by the club. Feedbacks were given, as they also did some simple reflection writing activities distributed all across the program. The program was successfully conducted for at least two years. Due to its independent, and creative nature, the researcher speculated that the successful results of this rare-to-see club was a tribute to metacognitive learning. However, whether or not it was true, must be tested and checked as metacognitive learning would not be possible without prior awareness.

According to Shea et al, (2014) metacognition is comprehended as the students' consciousness of their own authentic ability on specific skills. Experts agree that students who are aware of their own learning process are more likely to be successful in their learning as compared to those who are not (Mbato, 2013; Nosratinia, Saveiy and Zaker, 2014; Jaleel, 2016). This awareness involves the students to conduct self-reflection on their own thinking and knowledge, and it can be trained along with their learning process. However, some effective instruments are needed to facilitate the learners in nurturing their metacognitive awareness. In this research, feedback giving and reflection writing are expected to be the two effective ways to assist students in cultivating their metacognitive awareness. The researcher sought to monitor the metacognitive awareness level possessed by this independent learning group. The focus of this research is to monitor the metacognitive awareness of several Civil Engineering students who were engaged in the English club. To answer the objective of the research, the researcher raised a question; how did the Civil Engineering students cultivate their metacognitive awareness to boost their independent English learning activities?

Since metacognitive awareness is a crucial instrument to monitor speaking for a group of independent learners, the focus of this research is to monitor the Metacognitive Awareness found in English Speaking Club of Civil Engineering Students. All of those utilized to analyze the correlations between the significant elements of the group's learning. The study on both metacognition and metacognitive awareness are popular and has been done several times recently. Hong-Nam (2014) and Jaleel (2016) studied the awareness and reading strategies exhibited by secondary school English language learners. Ruan (2014) investigated the awareness in writing displayed by Chinese learners. Rahimirad and Shams (2014) explored metacognitive awareness in listening performance. Cosgrove and Slattery (2014) probed the implementation of critical writing in a civil engineering program in an American university context. Meyer et al (2015) monitored metacognitive assessment activities on two associates of civil engineering program in an Australian context. Review similar studies in Indoensian context leading to your topic. This research focuses more on investigating the metacognitive awareness level of a group of Civil Engineering (CE) students who were members of the independent speaking English club in Yogyakarta, Indonesia. This study tried to explore 
whether or not metacognitive awareness was utilized by a group of independent learners in developing learning strategies to increase their English speaking ability. This segment incorporates the theory of metacognitive awareness, speaking, and learning strategy. These theories are developed as a framework to elaborate the points in this research.

As the major point of this research, metacognitive awareness (metacognition) is conceptualized as the interaction between how the environment can stimulate individual awareness and how the mind serves as an initiator for judgments and evaluations need further explorations. The results of such research can serve to illuminate the mechanism of metacognition, SR, and SRL that can lead to appropriate instructional interventions to promote thinking and learning (Mbato, 2013, p. 24). Tuysuzoglu and Greene (2015) elaborate that a metacognitive approach compels learners to not only have their own self-awareness, and regulation, but also the suitable strategies for their learning. These strategies would the ones that are suitable in assisting them in doing different tasks. The strategies must specifically suit the requirements of the objectives. Lajoie and Pitras (2014) emphasized that metacognitive awareness is also vital to the growth of self-regulated learning. They explained that to be a more successful learners, students need to be self-regulated in their learning, and to be self-regulated, they need metacognitive awareness.

In supporting the theory about metacognitive awareness, Mbato (2013, p. 38) argues that selfawareness and self-regulation are significant to learners' cognitive growth. In similar sound, Ruan (2014) suggests the importance of metacognitive awareness in augmenting both learners' learning progress and self-regulation. Without awareness as the igniting push, none of the metacognitive processes might occur. The researcher was also interested in probing the actual interaction between metacognitive awareness of CE English learners and the contextual environments of speaking learning strategies (cf. Lajoie and Pitras, 2014; Mbato, 2013). Lehmann, Hähnlein, and Ifenthaler, (2014) suggested that awareness should be continued by a corresponding level of motivation and a sufficient amount of determination so that proper strategies towards their learning can be properly applied. From those theories, it is referred to the researcher that metacognitive awareness is the stimulation for the user in order to enact personal capability to make independent criticisms and evaluations by recognize the strength and limitations. Then, the learner of this approach can solve the problem in several sequences such: learning process and working life. In this study, awareness will be the main focus to monitor the CE English learners, whether or not their awareness impacts their regulation in learning strategies directly.

In the process of grasping knowledge, $\mathrm{CE}$ English learners have to monitor their learning strategies. It is a mental process which requires the ability of realizing which requires metacognition. Moritz and Lysaker, (2018) based on James Flavell's description, explain that metacognition is simply explained as "thinking about thinking (p. 906)". Metacognitive awareness stimulates own reflection to figure out personal lack and needs. By possessing it, learners are able to regulate self into learning strategies which has been adjusted by their strength. Mahdavi (2014) implies that metacognition refers to one's ability to know and regulate cognitive processes. As adult learners of English, implementing metacognitive awareness will be significant for CE English learners to navigate learning development in many other aspects such as: self-regulation, motivation, and also volition. These are the keys to successful learning (Mbato, 2013).

Second point is speaking. Nunan (2015) argues that speaking, among the four skills, is the most challenging one as it occurs "real time"; spontaneously. It is a continuous and flowing process 
that demands the speaker to keep talking in response to the other's speech. It is also challenging for learners because once a speech is uttered it cannot be retracted, or edited. Kendon (2014) conveys the term "producing systematic verbal utterances (p. 48)" with the purpose of delivering meaning to the listener.

Speaking proficiency in a foreign language can be very difficult. Bailey's (2003) dichotomy on the differences between spoken languages uttered through speaking with the written language delivered by writing. There are five aspects that are compared, namely: 1) while written language is visual, spoken language is auditory, 2) while written language is permanent spoken language is temporary, 3) written language counts on punctuation while spoken language counts on rhythm and stress intonation, 4) written language requires delayed or no feedback while spoken language requires immediate feedback in its nature, and 5) in producing written language, people can do an unlimited planning, editing and revising their oral discourse.

Bailey (2003) and Hornsby (2015) agrees to the notion that speaking skill should be nurtured through conversational practices, thus the Cooperative Language Learning (CLL) was invented to facilitate the learners' need. Heterogeneous learners may learn through conversations and interactions with one another. EFL learners in group are stimulated to contribute "keep affective considerations firmly in mind" (Murphy, 2003, p. 116). This means that the affective side of learning such as motivation, peer-feedback and efficacy must be well-monitored so as to support the progress. Motivation and comfort can be boosted by implementing speaking game and related topic from listening media as the learning strategy. When the language is being used to communicate, that is to deliver meaning; learners are honing their foreign language speaking skill. In practicing speaking, learners should pay attention on the grammatical aspect of their speech so that they can deliver meaning in the correct and meaningful logical order. Beyond their understanding on how to pronounce phonemes, syllables and even morphemes, Bailey (2003) suggests that learners should master words, phrases, clauses, utterances, and last but not least, texts. There are several principles for teaching speaking, suggested by Bailey (2003). 1) Foreign language learners are expected to retain more effort in practices, 2) the success of the learning relies on the number of opportunity to practice fluency and accuracy, 3) constructive grouping and talking in pairs are highly beneficial, 4) meaning negotiations must be trained and practiced all the time, and 5) the practice of transactional and interactional speaking must be planned beforehand in the activity set.

The information gap is helpful to be practiced. It means to give the students the topics to practice. Activities such as Jigsaw and role playing should help too (Bailey, 2003, p. 64). Not everybody has speaking ability as the strongest point. Keep training is key to improve it. It is because speaking skill needs good planning in terms of the material that will be delivered, and a sufficient range of vocabulary (Hornsby, 2015). When learners find the appropriate word, it can help them to develop the content of speech. The researcher does agree with Bailey (2003) that speaking is possibly the most challenging out of four basic skills in English language learning. It needs to be trained over and over again until learners master the target discourses (Kendon, 2014).

Last but not least, the thing which is prominent to be discussed is about learning strategies. Griffiths and Oxford (2014) argue that learning strategies in second language learning is important. According to O'Malley and A. Chamot, there are at least five reasons on why learning strategies must be promoted. 1) Metacognitive awareness leads to better learning process, 2) learners with knowledge on their strategies tend to strategize their learning better, 3) learners who are knowledgeable about learning strategies are capable to utilize different 
strategies for different challenges, 4) coaching in learning strategies increases students' motivation, and 5) learners who strategize their learning are capable of independent learning and self-reliant.

Griffiths and Oxford (2014) further elaborate how learners with strategies stored in their mind would have the capability also to adjust the priorities of their language comprehension skill developments. Learners who want to attain good speaking skill in the target language would listen more; they would conduct listening activities more often to increase their knowledge on the target languages' spoken sounds, its pronunciation, and the way sentences are arranged to be delivered verbally. Learners who aim to be able to write in the target language would first direct their learning into conducting some reading activities. With the model given in the target language, learners are learning to first, mimic the discourse, and later to produce a similar discourse in with their own progress.

In her discussion on Issues in Language Learning Strategies Research and Teaching, Chamot (2004) revealed four steps in strategic learning, namely "planning, monitoring, problemsolving, and evaluating (p. 17)". To be successful in their learning, learners must first set-up their goal. They must plan and schedule their learning: how many meetings they will have in a week, how many hours will they spend on studying a certain skill, etc. The second step is monitoring in which learners must be able to control and monitor whether or not they are working with the plan. Are their activities coherent with the planned ones, or are their activities relevant to the targeted objective? The third one is problem-solving. In this step, learners must have the capability to identify any factors that are hampering their progress in achieving the learning goal. Identifying the problem is not enough because they must also reflect upon what might be the causes of the problems, and how the problems could have been avoided. Last but not least, it is stated that in the end, strategic learners are the ones who can evaluate their strategies implied in their learning activities. The positive ones should be kept and developed, and the unsupportive ones should be discarded. In this way, the learners grow in their progress (Chamot, 2004; Mbato, 2013; Griffiths and Oxford, 2014).

\section{METHOD}

In answering the question, semi-structured interviews, observations, and analysis on learners' reflections were utilized. This research was a participatory classroom action research in an informal class. The researcher utilized qualitative instruments in collecting the data modelled after the one proposed by Mertler, (2016) while being directly involved into the process. The participants of the research were 42 students of Civil Engineering study program in a private university in Yogyakarta, Indonesia. The participants belonged to the 7th and 9th semester classes of Civil Engineering. They got English class only in the first and second semester. The material was divided into two. It consisted of general English in daily conversation, whereas the last part delivered the technical terms related about their workplace and job description to be.

The participants were in their twenties. There were four males and six females. They came from various ethnics and family background from all around Indonesia. Related to English learning background, they have different experiences. Some of them had taken a course in formal institutions and had a TOEFL score. About ten of them had had the opportunity to go abroad for a seasonal student exchange, travelling, and occupational purposes. Almost half of them admitted that they really got a difficulty time in conversing in English during the placement 
test. The researcher was interested to assist the students' by introducing reflection and giving feedback to facilitate their metacognitive awareness growth.

The researcher adapted the model suggested by Kemmis, McTaggart and Nixon (2015) consisting of Plan, Act and Observe, and Reflection in observing. There were three surveys. The first survey was accomodated in the first five weeks. This was the pre-survey stage. The middle stage was conducted for the next five weeks, and the post, the third, post survey to close the process. The questions of the interview, as well as the guiding aspect of the observation were derived from the "Metacognitive Awareness Inventory" (MAI) questionnaire design suggested by Schraw and Dennison (1994). The questions were including the learning result during the first two semesters, and also recapping the two year period of their English club. The questions were set to find out the previous awareness level of students and to find out the latter awareness level as the results of the actions implemented during the research good. According to Mbato (2013), the habit of feedback and reflection were elaborated to stimulate their metacognition in constructive learning strategy. The really new thing for them was being a discussion group to study English. It could be inferred that teacher centered was the main point of their English learning.

This study employs the qualitative approach. The qualitative approach is applied to study the participants' behavior in naturalistic settings, providing holistic insights into educational processes experienced by the participants in specific educational settings (Creswell and Poth, 2017). In addition, applying the qualitative approach also provides in-depth and rich information about the participants' personal meaning (McDonough and McDonough, 2014). The information on metacognitive awareness as portrayed as CE English learners' experience was the main data. Then, it was analyzed and displayed in the form of description. The personal interview was the main instrument of the research. Biographical approach by Gibbs (2018) was applied to analyze the verbatim transcripts. The researcher's anecdotal field notes also used to support the main data. The study was conducted in Yogyakarta, Indonesia, during August up to October 2018.

\title{
RESULTS AND DISCUSSION
}

\section{Results}

The focus participants of this research were two females and two males; Abby, Reni, Ahmad and Edho (pseudonyms). They were picked to represent the majority of the learners, in which their experiences were the most unique and engaging among the rests of the learners. These four participants were also the last standing participants of the English club before it was disbanded after they graduated.

\begin{abstract}
Abby
The first participant was Abby. She liked to read English novels and magazines. She prepared herself by taking some English courses until her graduation. In these long terms, capability to reach professionalism as a career woman became her focus. She knew that her miss point was her inflexibility in handling conversation. Through English Club, she was coping her personality to be more initiative in had positive vibeShe felt impressed that English Club can help her to. She was strong in written English, but lack of confidence in practicing her public speaking. After the second meeting of English club, she decided to have live International TV Channel. She started from listening English as entertainment. She thought that it was appropriate learning strategy because she had a need in being familiar with some English terms. When asked about her strategy she said: "Listening helped me to be familiar with some terms
\end{abstract}


before I apply them in speaking." This emphasized the aspect of listening as the important tool to improve the English speaking need.

According to Nunan (2015), listening was the dynamic process of "making sense of what was heard with a certain purpose". He emphasized that listening was actually a very active and not a passive skill. While listening, people were looking for meaning by connecting the information that they heard, to the one that they knew (p. 24). This act of combining ideas helped learners building comprehension. Several media employed in learning strategy for CE EFL Learners such as: TED Talk, Buzz Feed, and BBC Science Documentary. In doing the activity, learners should be able to focus on the listening material. When they were not doing so, it was very easy for them to miss all of the information. The use of interesting topics would maintain their motivation in learning English. Some topics were relatable and close to them or even something new which could trigger their curiosity. The top-down processing could reach the students more personally when related to the listening content. In the other hand, the bottom-up processing was more difficult as it might seem. It would enhance the students' vocabulary (Rahimirad and Shams, 2014). The most important thing from listening as the first step of learning strategy was making CE EFL learners feel familiar with general terms.

Abby was a metacognitive learner. She clarified her purposes for learning. She exhorted several strategies to reach her objectives. She also had metacognitive awareness. This can be seen on the pattern of her learning in which she believed that listening enhanced her speaking. Through doing extra listening performances she enhances her speaking progress. She cultivated her awareness by joining the English club so that through her friends' feedback she could always have her progress monitored. Her writing ability enhanced her motivation in which this also boost her regulated learning. Pre- post according to your AR method?

\section{Reni}

The second participant was Reni. Reni had the same age with Abby. At the first time, she chose CE study program because of avoiding language discipline and family background. The interview from her partner in the English Club which had been confirmed by her, she had negative attribution with her English teacher in elementary school. She had an English regular course in a private institution, but she felt it was not effective because she felt anxiety to speak up. In the fact, she knew that English was important for her future. Her decision in joining English Club was influenced of lack motivation and limited chances for her to practice her English public speaking skill in the class. When asked about her feelings in joining the Club she said "This group discussion helped me to reduce anxiety and improve motivation. I have a certain pattern to aware my achievement and manage my limitation".

The second participant with her Cooperative Language Learning (CLL) group carried an understanding on the concept of whole-person learning as explained by Richards and Rodgers (2014). The relationships between learners' intellectual, emotional, psychomotor, protective instinct and learning passion aspects in building the individual's learning. CE English learners as adult learners often felt unsecure by a new learning environment. They tent to worry about the results and the social judgment on their performance. Having comfort and positive energy could be gained in this type of learning. In the CLL, language was to be spoken and practiced for the learners to be able to use it. Learning was persons. The whole-person learning should be supportive in trustworthy environment. Because learning was dynamic and creative, so the 
process was ongoing and it would take some time for the learning to yield its result. The listening and speaking skill were potential to be accommodated by CLL.

There were several elements of successful group-based learning. First thing was positive interdependence. The learners must show their own personal effort to see how far they had progressed, and to wait feedbacks from their fellow learners, and learnt from it. Group activity would help the learners to achieve a better understanding on the subject matter as fellow learners could support each other by responding to and helping their peers. Second, there was a group formation consists of 4-8 learners and a coordinator. Third, the learners must have the confidence to speak-up no matter how uncomfortable it was.

The individual accountability which was figured out would enact the social skill of EFL learners. The learners were to interact with their fellow learners verbally in the target language. The content in which they were speaking with was about daily conversation, so it had also the socialaffective side of it too, like asking the well-being of others, and so on. The learners were to encourage themselves and each other to interact. Asking questions when they didn't understand, or maybe giving out ideas for the learning in semi-formal manner. They could interact freely without burden, yet there was a small quiz or dictation in the end of session. Learners were the subjects of the class as they were the focus of the learning development. They were learning from each other in a scaffolding-like framework. In addition, the material was the characteristic of CLL. The learning material was not to give the learners too much pressure but still had an element of intriguing challenges for the learners to grow up on.

The research showed that Reni, as diligent as she had been, was a non-independent learner. She relied heavily on others as she failed to gain confidence in her own capability. The learning objectives were vague as she struggled with "mending the past". However, thanks to her diligence and the cooperative learning, she managed to keep up with the pace. She was not aware of her strengths as well as weaknesses, now was she capable of framing a strategy for her learning. It was due to the club and her colleagues at the club that she was able to progress eventually.

\begin{abstract}
Ahmad
Ahmad was 25 years old. He used to be a part time drafter. He had been working for three years. He had good ability in technical drawing. In the contrary, he lacked in English speaking comprehension. English was a subject that he sometimes avoided. He felt bored about written tasks. His purposes in joining English Club were to be familiar in listening English terms and have partner in learning language. He was aware that he had difficulty to focus. If there was a chance to make more money, he would prefer that to learning. That's why he skipped up some meetings. After he graduated, he had a better job in Jakarta. As a junior engineer on the job training, he had to deliver the company tenders in English. He got a shortcut. He said that it was easy to find a translator for his slides, but he had a moment which indicated him to improve his English public speaking ability. His experience as new comer reminded other language learners and researcher that learning language was a process. A process needed motivation to start, but self regulation was the engine.
\end{abstract}

Ahmad was also not metacognitively aware as he failed to prioritize his objectives in learning. He was a bit hesitant during his process as he prioritized work over learning. From professionalism's point of view he did give a lot of effort. From learning point of view, he was not trying enough to reach his learning objectives nor did he try to strategize his learning. As they were no problem solving from his personal view, Ahmad was not a regulated learner. 


\section{Edho}

Edho was the oldest participants in his batch, Civil Engineering 2014. He was 29 years old. He was a first child born. In the researcher's hypothesis, implementing discipline and critical thinking was not the new habit for this participant. He always kept noting every importan or new things. Although not his favorite class, he could find out his 'to improve' list in English. He was also cooperative in facilitating the English Club for example choosing the topic and the game. His creativity in tutoring this non-formal class because he adapted the way of English teacher taught in his previous study. According to his notes, the researcher also analyzed that he had good self-regulation ability in allocating time between working and joining the English speaking club.

Self-regulation could exist because of possessing metacognitive awareness. To be strategic, learners had to regulate their self into learning process. Without having metacognition, a learner could not apply self-regulation. Mbato (2013) argued that self-regulation skills had the possibility to recall positive emotions in which they were supportive to the cognitive aspect of learning. This was why self-regulation was a major issue that could affect CE English learners' learning. The research findings suggested that many $\mathrm{CE}$ English learners found that metacognitive awareness followed by self-regulation learning strategies were interrelated. They could be beneficial in terms of skill mastery, such as: speaking. The advantages of the implementation of metacognitive awareness and self-regulated learning strategies will empower CE English learners to deal with their thinking, time management, learning needs and limitation through their learning strategy.

Knowing where to go and what to do were Edho's strengths. He was highly cooperative and regulated in his process of learning. He strategized his learning by making schedules on his activities. He had his learning and working monitored. He even took note on his progress. He was clearly aware of his strengths and weaknesses and exhorted some strategies to overcome the problems. Edho nurtured his metacognitive awareness by writing, when he wrote down his thoughts, he activated his metacognition. Hence, he was also a successful learner because he achieved good results from his learning process with the club.

\section{Discussion}

Metacognitive awareness can be applied in all aspects of teaching and learning processes. Those four characters in the result guide us how prominence of having metacognitive awareness. Some learners determine the learning objectives, what kind of skill that they need more and able to be executed. They continue the step to select of material and learning strategy, assessing entering proficiency, and predicting difficulties. The next step is planning-in-action which consists of monitoring, evaluating outcomes, and revising plan. Learners, who are metacognitive, have more accurate knowledge monitors than the poor ones. They plan, generate question, choose consequences of behaviors, evaluate, take credit for actions, keep journals to record the process.

The difficulties of some learners above are considered from three points. First thing is a certain skill which they want to master. Second, there is a particular academic domain which consists of unfamiliar even complicated terms. Third, it's based on learners' characteristics and strategies in learning language. Some strategies to overcome the difficulties are using dictionary and electronic device to find the meaning of the new vocabularies, making note of some terms 
and how to apply in sentences, relistening several times to get better understanding, arranging the group meeting to practice and share the difficulties, and articulating the peer feedback to elaborate something that need to be improved in learning. Language learning is circular and open ended process. Learner are taking control of learning. It is related with self-regulated learning. Because of different perceptions on being succesful engineer, time availability, and the existence of working load, there is a speaking group member who put learning English after their job priority.

\section{CONCLUSION}

Metacognitive awareness was vital in facilitating self-regulated learning. Self-regulated learners strategized their learning, monitor their progress and innovate their endeavours. The researcher conducted a qualitative action research on four specific Civil Engineering undergraduate students from Yogyakarta, Indonesia. The four participants were the last members to join an informal English speaking club at their university. Among four learners two were metacognitively aware, and the other two had good experience in learning English. The two students who were metacognitively aware were using listening and writing as their strategies in nurturing their self-regulated learning. From the research it could be concluded that independent learning can be facilitated and born from cooperative learning. Cooperative learning builds up learners' motivation through peer feedbacks and monitoring done by a tutor. Metacognitive awareness was built upon the realization of clear learning objectives, followed by self-determination, and planning. Consistency is also required to sustain self-regulated learning.

Due to the time limitation, the researcher was not able to discuss even more participants. Further research on the relationship between motivation and self-regulation, and metacognitive awareness with motivation in Civil Engineering students' context are needed. If readers are interested in similar topic, readers may conduct some research on the factors contributing to the birth of metacognitive awareness in beginning learners of English for Specific Purposes.

\section{ACKNOWLEDGMENTS}

We thank to the anonymous respondents and all member of English Speaking Club of a Private University in Yogyakarta. This research is paid by personal financial support of researchers.

\section{REFERENCES}

Al Hosni, S. (2014). Speaking difficulties encountered by young EFL learners. International Journal on Studies in English Language and Literature (IJSELL), 2(6), 22-30.

Bailey, K. M. (2003). Speaking. Practical English language teaching, 47-66.

Basturkmen, H. (2014). Ideas and options in English for specific purposes. Routledge.

Chamot, A. U. (2004). Issues in language learning strategy research and teaching. Electronic journal of foreign language teaching, 1(1), 14-26.

Cosgrove, T., \& Slattery, D. M. (2014). Implementing reflective writing in a problem-based learning civil engineering programme.

Creswell, J. W., \& Poth, C. N. (2017). Qualitative inquiry and research design: Choosing among five approaches. Sage publications.

Crystal, D. (2012). English as a global language. Cambridge university press. 
Fitriandi, P., Kakinaka, M., \& Kotani, K. (2014). Foreign direct investment and infrastructure development in Indonesia: Evidence from province level data. Asian Journal of Empirical Research, 4(1), 79-94.

Gibbs, G. R. (2018). Analyzing qualitative data (Vol. 6). Sage.

Griffiths, C., \& Oxford, R. L. (2014). The twenty-first century landscape of language learning strategies: Introduction to this special issue. System, 43, 1-10.

Hong-Nam, K. (2014). ELL High School Students' Metacognitive Awareness of Reading Strategy Use and Reading Proficiency. Tesl-Ej, 18(1), n1.

Jaleel, S. (2016). A study on the metacognitive awareness of secondary school students. Universal Journal of Educational Research, 4(1), 165-172.

Hornsby, M. (2015). The "new" and "traditional" speaker dichotomy: Bridging the gap.

Kemmis, S., McTaggart, R., \& Nixon, R. (2015). Critical theory and critical participatory action research (pp. 454-464). Los Angeles, CA: Sage.

Kendon, A. (2014). Semiotic diversity in utterance production and the concept of 'language'. Philosophical Transactions of the Royal Society B: Biological Sciences, 369(1651), 20130293.

Lajoie, S. P., \& Poitras, E. (2014). -Macro and Micro Strategies for Metacognition and Socially Shared Regulation in the Medical Tutoring Domain. Design Recommendations for Intelligent Tutoring Systems, 151.

Lehmann, T., Hähnlein, I., \& Ifenthaler, D. (2014). Cognitive, metacognitive and motivational perspectives on preflection in self-regulated online learning. Computers in human behavior, 32, 313-323.

Mahdavi, M. (2014). An overview: Metacognition in education. International Journal of Multidisciplinary and current research, 2(3), 529-535.

Mbato, C. L. (2013). Facilitating EFL learners' self-regulation in reading: implementing a metacognitive approach in an Indonesian higher education context.

McDonough, J., \& McDonough, S. (2014). Research methods for English language teachers. Routledge.

Mertler, C. A. (2016). Action research: Improving schools and empowering educators. Sage Publications.

Meyer, J. H., Knight, D. B., Callaghan, D. P., \& Baldock, T. E. (2015). An empirical exploration of metacognitive assessment activities in a third-year civil engineering hydraulics course. European Journal of Engineering Education, 40(3), 309-327.

Moritz, S., \& Lysaker, P. H. (2018). Metacognition-what did James H. Flavell really say and the implications for the conceptualization and design of metacognitive interventions. Schizophrenia Research, 201, 20-26.

Murphy, E. (2003). Monolingual international schools and the young non-English-speaking child. Journal of Research in International Education, 2(1), 25-45.

Nosratinia, M., Saveiy, M., \& Zaker, A. (2014). EFL learners' self-efficacy, metacognitive awareness, and use of language learning strategies: how are they associated?. Theory and Practice in Language Studies, 4(5), 1080.

Nugraha, A. (2018). Politik Pembangunan Era Jokowi (Studi: Peran Pemerintah Tiongkok dalam Pembangunan Infrastruktur di Indonesia).

Nunan, D. (2015). Teaching English to speakers of other languages: An introduction. Routledge.

Rahayu, R., \& Day, J. (2015). Determinant factors of e-commerce adoption by SMEs in developing country: evidence from Indonesia. Procedia-Social and Behavioral Sciences, 195, 142-150. 
Rahimirad, M., \& Shams, M. R. (2014). The effect of activating metacognitive strategies on the listening performance and metacognitive awareness of EFL students. International Journal of Listening, 28(3), 162-176.

Richards, J. C., \& Rodgers, T. S. (2014). Approaches and methods in language teaching. Cambridge university press.

Ruan, Z. (2014). Metacognitive awareness of EFL student writers in a Chinese ELT context. Language Awareness, 23(1-2), 76-91.

Schraw, G., \& Dennison, R. S. (1994). Assessing metacognitive awareness. Contemporary educational psychology, 19(4), 460-475.

Shea, N., Boldt, A., Bang, D., Yeung, N., Heyes, C., \& Frith, C. D. (2014). Supra-personal cognitive control and metacognition. Trends in cognitive sciences, 18(4), 186-193.

Tuysuzoglu, B. B., \& Greene, J. A. (2015). An investigation of the role of contingent metacognitive behavior in self-regulated learning. Metacognition and Learning, 10(1), 77-98.

Tsiplakides, I., \& Keramida, A. (2009). Helping Students Overcome Foreign Language Speaking Anxiety in the English Classroom: Theoretical Issues and Practical Recommendations. International Education Studies, 2(4), 39-44.

Yamin, M., \& Windymadaksa, S. (2017). Pembangunan Kereta Cepat Jakarta-Bandung Sebagai Mercusuar Hubungan Indonesia-Tiongkok. Jpp (Jurnal Politik Profetik), 5(2), 200-218. 